him ... to make a globe of the moon, and likewise to continue the description of severall insects.

A report was made of the trial of the dyving engine at Deptford on Friday preceding, by the amanuensis, who stayed in it eight and twenty minutes under water.

Mr. Henshaw read his History of the Making of Saltpetre.

Mr. Boyle to try the velocity of sounds."

Space does not permit the description here of the great number of tests, measurements, and reports which were brought forth; the names alone must suffice to recall the fundamental character of many of the researches produced. Boyle, Hooke, Wallis, Petty, Wren, Willis, Glisson, of the original fellows; Newton, and Mayow, among those who followed soon, are all household names in their sciences to-day; and the records speak of many others, less familiar now, but still valuable contributors to learning who were rightly honoured in their day.

It is evident from Pepys' and Evelyn's diaries, as well as from surviving correspondence, that the activities and the aims of the Society made a wide appeal among educated people; and there is in the British Museum a long and amusing doggerel poem which shows how strong and affectionate a respect was inspired among its lay supporters of the early 'sixties. Hostile critics were, naturally, not lacking, and it was to answer these that Sprat was egged on by Wilkins and others to write his well-known "History of the Royal Society," and that Joseph Glanvill produced his delightfully vigorous "Plus Ultra."

The fundamental principle upon which the Society was based, as is clear from many documents both official and private, was the Baconian doctrine. Croone writes in $166 \mathrm{I}-$

“. . . you may please to understand that this Company do's not take upon it selfe to assert any one hypothesis, but every man is left at present to his Freedom; for they believe that to make any Hypothesis, and publickly owne it, must bee after the triall of so many exp'ments as cannot be made but in a long tract of time."

In the draft of a minute, probably written by Hooke about 1663 , and now in the British Museum, we find-

"This Society will not own any Hypothesis, Systeme, or Doctrine of the principles of Naturall Philosophy, proposed or maintained by any philosopher Auncient or Moderne, nor the explication of any phaenomenon, where recourse may be had to originall causes. . . Nor dogmatically define, nor fix Axioms of Scientificall things, but will question and canvas all opinions, adopting nor adhering to none, till by mature debate and clear arguments, cheifly such as are deduced from legittimate experiments, the trueth of such positions . . be demonstrated invincibly."

Boyle's "Sceptical Chymist" is, of course, an outstanding exposition of the same theme, upon which the whole existence of the Royal Society rested, and rests.

\title{
The Natural History of the Common Eel.
}

\section{By J. T. Cunningham.}

THE propagation of the eel was a mystery not only to ordinary people, but also to naturalists, from the time of Aristotle to the end of the nineteenth century, and continued to be a mystery for years after the breeding and development of many other fishes, both marine and fresh-water, had been successfully studied and investigated. At present our knowledge of the development of the eel is almost but not quite complete, and the extraordinary facts of the matter have been brought to light chiefly by the adventurous and persevering efforts of the Danish naturalist, Dr. Johannes Schmidt, of Copenhagen, who has published a memoir on his researches in the Philosophical Transactions of the Royal Society of London and has described them in articles in NATURE (August 22, I912, and January $1_{3}, 1923$ ).

The gradual elucidation of the history of the eel started from our knowledge of a very curious group of fishes named Leptocephali, which means "Smallheads." They were so named from the fact that the head is very small in proportion to the body, which is like a narrow ribbon $\frac{1}{2}$ to $\frac{3}{4}$ in. in breadth and from 3 to 6 in. in length. The surfaces of the ribbon are the right and left sides of the fish, so that the breadth is vertical in the natural position, and the whole creature is perfectly transparent. The newly hatched young of many fishes are transparent, but they are usually of minute size, while the Leptocephali are much larger. These remarkable creatures had been collected from time to time, some at the surface of the ocean in various parts of the world, some cast on the shore in England or other parts of Europe. Various species of them were distinguished, but for a long time there was nothing to show what relation they bore to other fishes. It was evident that they were not mature, and some naturalists suggested that they were monstrosities, that they were the young of some ordinary fishes which from time to time were accidentally carried into mid-ocean by currents, and there went on growing in size without advancing in structure, that they were in fact overgrown fish-larvæ which were unable to complete their normal development because they had been removed from their normal conditions of life. Gradually, however, evidence presented itself that these Leptocephali were connected with the eel family.

Although there is only one fresh-water eel in Europe and another very similar in North America, there are many species of the same family in the sea, some living at moderate depths and some in the deep abysses of the ocean. On the Atlantic coasts of Europe there is only one marine species, the well-known conger, which reaches 7 or even $8 \mathrm{ft}$. in length, but there are several species in the Mediterranean, one of which, the Muræna, was a favourite article of food to the ancient Romans. The species of the eel family are similar in certain important features of structure to the herring family, the salmon family, the carp family, and others, but they are distinguished by the entire absence of the hinder pair of fins. In this and other details of structure, such as the number of the vertebræ, the Leptocephali agree with the eels. In particular the Leptocephalus morrisii, several specimens of which form had been captured

$$
\text { NO. } 2832 \text {, vOL. II } 3 \text { ] }
$$


on British and French coasts, was considered to be probably the young of the conger. At last in $1886 \mathrm{a}$ specimen of this form, taken at Roscoff in Normandy in February, was kept alive, and in the period between this month and July actually changed into a young conger, which was dark in colour, cylindrical in shape, and shorter than in the original condition.

After this it appeared extremely probable that the various Leptocephali were the normal young forms or larvæ of various species of the eel family, and that the early condition of the common eel was probably a transparent ribbon-shaped Leptocephalus.

In the years I891-1894 an Italian professor, G. B, Grassi, and his colleague, Signore Calandruccio, studied carefully the Leptocephali which they obtained at Catania, on the east coast of Sicily. In this neighbourhood, especially near Messina, it had long been known that these peculiar fishes were rather abundant. One of them had been distinguished as brevirostris or short-snouted. The Italian naturalists now proved that this particular form changed into the common eel, and, as in the case of the conger, the perfect young eel was smaller and shorter than the ribbon-like form from which it developed: the latter reaches the length of $3 \frac{1}{4}$ in. with a breadth (or vertical height) of $\frac{2}{5}$ in. $(0.4$ in.), and it develops into a slender thread-like dark-coloured elver about 2 in. in length.

Elvers, that is to say, young recognisable eels 2 to 3 in. in length, but not less than 2 in., were long known to ascend rivers in enormous numbers in spring. On the banks of the Severn, for example, these little fish can be seen at the right season, March and April, passing up along the banks in countless millions, and the people of the neighbourhood are in the habit of dipping them out of the water with hand nets, and making fish-cakes of them, or otherwise cooking them for food. On the other hand, adult eels are captured in large numbers in autumn passing down the rivers towards the sea, and in Denmark and other places these migrating eels have been shown to be more silvery in colour and to have larger eyes than ordinary specimens. With one or two exceptions none of them have large roes, so that the exceptions must be regarded as abnormal, and the vast majority of eels go down to the sea to breed, and the young eels come up from the sea to the rivers and fresh waters. There is no evidence that the adult eels ever return from the sea after their migration. It.is true also that the male eels are usually found in estuaries or near the mouths of the rivers and do not ascend so far as the females.

It was improbable that the eel larvæ should exist only near the coast of Sicily, or only in the Mediterranean, and Dr. Schmidt was first led to give his attention to the subject by the capture of a specimen of Leptocephalus brevirostris from the sea near the surface to the west of the Faroe Islands in the far north of the Atlantic. As a result of this it came about that Denmark, where the eel fishery is an important industry, undertook the task of carrying on the investigation of the eel question, and the direction of the work was entrusted to Dr. Schmidt. This work has been continued from 1904 to $\mathbf{I} 922$ with some interruptions. It consisted chiefly in fishing with special nets in order to ascertain where the larval eels were to be found, at what seasons, and what was their size and condition at each part of the sea. The earlier cruises were made in the steamer Thor, which was owned by the Danish Government and specially equipped for marine research. It was found that the Leptocephali of the common eel were found in numbers in the Atlantic from the Faroes to Brittany, outside, i.e. to the west of, the 500 fathom line, but not to the east of it. It was shown that in August and September the larvæ were undergoing "metamorphosis" or transformation into the perfect eel, and it was evident that the fully developed elvers appearing at the mouths of rivers in spring were derived from the Leptocephali of the previous summer and were at least one year old.

The next task was to discover where the younger larvæ occurred. Those above mentioned were the largest in the Leptocephalus stage, just before metamorphosis, and little less or more than 3 in. in length. The Norwegian naturalist, Dr. Hjort, in an Atlantic expedition obtained 2 I specimens to the south and west of the Azores, and these were only 2 in. in length. It was supposed that these were a year younger than the others and that the actual spawning place was between the Azores and Bermudas. Further collections were made, partly from Danish liners on their voyages across the Atlantic between the English Channel and the West Indies, the special towing-nets for young fishes being supplied to them to be used for an hour or so when possible, and partly from a cruise by a special small schooner called the Margarethe fitted out for the purpose. This ship was wrecked in the West Indies, but the collections were saved. It was found that the smallest larvæ, from 9 to $2 \mathrm{Imm}$. in length, were taken in spring and summer about lat. $26^{\circ}$ N., long. $55^{\circ} \mathrm{W}$., that is, in the Sargasso Sea.

Finally, a four-masted motor schooner, the Dana, of $55^{\circ}$ tons, was specially fitted out for the purpose of these researches. Expeditions on this ship were made in 1920 and I92I, and large numbers of the larvæ were collected at different positions in the western part of the North Atlantic. When the places of capture were plotted out according to the sizes of the larvæ, it was proved that all those less than to $\mathrm{mm}$. ( $\frac{2}{5}$ in.) in length were taken in the middle of the Sargasso Sea, and the larger sizes at increasingly greater distances from this region. This region must be regarded, then, as the spawning place of the European eel. It extends from $20^{\circ}$ to $30^{\circ} \mathrm{N}$. lat. and from $50^{\circ}$ to $65^{\circ} \mathrm{W}$. long. In one haul of two hours' duration in this region in June 1920 nearly 800 specimens were obtained, the largest number being $24 \mathrm{~mm}$., or very nearly I in., in length. These are considered to be in their first year, probably hatched a few months earlier. The elvers which reach the coast of Europe are calculated to be three years old. The depth of the ocean in the eelspawning area is from 3000 to 4000 fathoms.

There is one question on which Dr. Schmidt's evidence does not seem quite conclusive, namely, whether the eel spawns in the Mediterranean, or whether all the larvæ in that sea come from the Atlantic through the Straits of Gibraltar. There are no eels in the Danube, or in the Black Sea or the Caspian or any of the great rivers flowing into those seas. But there are eels in Egypt, in Greece, Italy, and Spain, and in particular a large eel fishery at Comacchio near Venice. We have seen that the particular Leptocephalus which belongs to the fresh-

NO. 2832 , VOL. I I 3 ] 
water eel was first identified on the coast of Sicily, and Dr. Schmidt has stated that the full-grown larvæ were not found by him east of the 500 fathom line, which is inconsistent with the view that they pass through the Straits of Gibraltar. It has been stated, also, that metamorphosed elvers are found at the mouth of the Nile in February, which is as early as, or earlier than, the time of their annual appearance on the west coast of Ireland, although the coast of Egypt is so much farther from the Atlantic breeding place.

On the other hand, Grassi and Calandruccio do not state that they obtained on the coast of Sicily the youngest and earliest stages of the Leptocephalus of the eel. The depth of the sea to the north of Sicily increases to more than rooo fathoms and it is possible that this is a sufficient depth for eels to spawn in, but if they do spawn there the very young larvæ and the eggs should be captured there. This brings us to the question of the eggs, and Schmidt himself has not yet obtained them from the Atlantic or identified them with certainty. On the other hand, Dr. Raffaele, an extremely able Italian naturalist, studied and described at Naples in $1885-1887$ a number of buoyant fish-eggs which, from the characters of the larvæ hatched from them, certainly belong to the eel family. The question is: Was one kind of these eggs the egg of the common eel ? One kind had a single oil globule in the yolk, and the youngest of the eel larvæ seen by Dr. Schmidt show asingle oil globule in the portion of yolk still unabsorbed. But the larva hatched from this egg, although certainly a Leptocephalus, has not been identified with the larva of the common eel. The question, therefore, whether the eel spawns and develops in the Mediterranean cannot yet be answered positively, though the above facts indicate the possibility, if not the probability, that it does so.

In conclusion, we may mention some remarkable facts concerning both the eel and the conger in the adult state. In the first place, there is a great difference between the sexes in size. The male eel seldom exceeds a length of 18 in., while the females may reach a length of $3 \mathrm{ft}$. or somewhat more. In the conger the difference is still greater. The present writer made a study of the conger for a considerable time at the Aquarium and Laboratory of the Marine
Biological Association at Plymouth. The largest male conger recorded was not quite $2 \mathrm{ft}$. 6 in. in length, while females $6 \mathrm{ft}$. in length are common, and specimens up to $8 \mathrm{ft} .3$ in. in length are on record. Secondly, although nothing has been seen of mature eels after their descent to the sea, observations of the present writer and one or two others on conger in the aquarium show that both sexes cease to feed when the reproductive organs begin to mature, and they live for three to six months without feeding, and finally die, the females without spawning, the males in a mature condition. When the females die the roes are enormously enlarged though the eggs are not quite mature. But a more extraordinary fact is that the bones have lost all their lime, and become soft as cheese, while the muscles are much reduced. The males before they die get into a much worse condition, the skin becomes ulcerated, the body emaciated, and the eyes so much diseased that the fish is quite blind. It is evident, therefore, that though the female conger is unable to spawn in the aquarium, this process taking place naturally at depths of more than rooo fathoms, both sexes spawn only once and die a natural death when the reproductive function has been accomplished.

Dr. Schmidt concludes from his discoveries that the fresh-water eel, which lives the whole of its life after its metamorphosis in inland fresh waters, but is hatched and developed in the sea and returns to great depths of the ocean to breed, is to be regarded as properly a marine fish. On the other hand, there is good evidence that the earliest bony fishes were evolved in fresh water, and some of the more primitive forms, such as the carp family, are still confined to rivers and lakes; few of them live exclusively in salt water. Migration from river to sea or sea to river is not uncommon among these more primitive fishes, as, for example, in the salmon family. Here the migration is in the opposite direction from that of the eel; salmon leave the sea and ascend rivers in order to spawn, and go down to the sea to feed and grow. The Pacific salmon (Oncorhynchus yschawitscha) offers a case almost as wonderful as that of the eel. It ascends great rivers of N.W. America and N.E. Asia to distances from rooo to more than 2000 miles from the coast, and, like the eel, spawns only once and then dies.

\section{O bitu a ry.}

\section{Rev. Prof. T. G. Bonney, F.R.S.}

$\mathrm{T}$ HOMAS GEORGE BONNEY, whose death on December Io was referred to in NATURE of December 15, was born at Rugeley on July 27, 1833 . His family is of Huguenot origin, and both his father and grandfather, the latter a fellow of Jesus College, Cambridge, were hard-working clergymen of wide and varied interests. After a distinguished career at Uppingham, Bonney entered at St. John's College, Cambridge, and in 1856 took a degree both in the Mathematical and the Classical Tripos.

Bonney was elected to a fellowship at St. John's in I859 and returned to the College in I86I as junior dean. A movement was then in progress to secure a wider recognition in the University for the study of natural science: this was joined by Bonney whole-heartedly, and one of the first results was an open exhibition in natural science offered by St. John's. In I 868 he was appointed tutor, and in 1869 lecturer in geology in the College. He had been interested in this subject from boyhood up, and his mathematical training had particularly fitted him for its pursuit. At this time Sedgwick occupied the chair of geology, but was prevented by failing health from exercising his functions as professor. The teaching of geology in the University devolved in consequence upon Bonney, who thus became the founder of the flourishing school which has given pre-eminence to Cambridge in this subject ever since. He was the first to introduce into English teaching the new petrology which had sprung from Sorby's application of the microscope to the study of rocks in thin slices, and his work has since been brilliantly developed by the labours, now continued for many years, of Dr. A. Harker.

As a tutor Bonney realised the ideal. Among those 